\title{
Isolation and characterization of equine peripheral blood-derived multipotent mesenchymal stromal cells ${ }^{1}$
}

\author{
Armando de M. Carvalho², Ana Lucia M. Yamada², Juliana R.B. Martins ${ }^{3}$, Leandro Maia4, \\ Marjorie A. Golim³ ${ }^{3}$ Elenice Deffune ${ }^{3}$, Carlos A. Hussni ${ }^{2}$ and Ana Liz G. Alves ${ }^{2 *}$
}

\begin{abstract}
Carvalho A.M., Yamada A.L.M., Martins J.R.B., Maia L., Golim M.A., Deffune E., Hussni C.A. \& Alves A.L.G. 2013. Isolation and characterization of equine peripheral blood-derived multipotent mesenchymal stromal cells. Pesquisa Veterinária Brasileira 33(9):1151-1154. Departamento de Cirurgia e Anestesiologia Veterinária, Faculdade de Medicina Veterinária e Zootecnia, Universidade Estadual Paulista, Distrito de Rubião Junior s/n, Botucatu, SP 18618-970, Brazil. E-mail: anaalves@fmvz.unesp.br

The objective of the study was to isolate, cultivate and characterize equine peripheral blood-derived multipotent mesenchymal stromal cells (PbMSCs). Peripheral blood was collected, followed by the isolation of mononuclear cells using density gradient reagents, and the cultivation of adherent cells. Monoclonal mouse anti-horse CD13, mouse anti-horse CD44, and mouse anti-rat CD90 antibodies were used for the immunophenotypic characterization of the surface of the PbMSCs. These cells were also cultured in specific media for adipogenic and chondrogenic differentiation. There was no expression of the CD13 marker, but CD44 and CD90 were expressed in all of the passages tested. After 14 days of cell differentiation into adipocytes, lipid droplets were observed upon Oil Red O (ORO) staining. Twenty-one days after chondrogenic differentiation, the cells were stained with Alcian Blue. Although the technique for the isolation of these cells requires improvement, the present study demonstrates the partial characterization of PbMSCs, classifying them as a promising type of progenitor cells for use in equine cell therapy.
\end{abstract}

INDEX TERMS: Immunophenotypic characterization, differentiation, mesenchymal stem cells, peripheral blood, equine.

RESUMO.- [Isolamento e caracterização das células mesenquimais multipotentes estromais derivadas do sangue periférico equino.] 0 objetivo deste estudo foi isolar, cultivar e caracterizar as células mesenquimais multipotentes estromais derivadas do sangue periférico (SpCTMs) equino. 0 sangue periférico foi coletado, seguido do isolamento das células mononucleadas utilizando o reagente de gradiente de densidade e o cultivo das células aderentes. Os

\footnotetext{
${ }^{1}$ Received on March 30, 2013.

Accepted for publication on August 10, 2013

${ }^{2}$ Departamento de Cirurgia e Anestesiologia Veterinária, Faculdade de Medicina Veterinária e Zootecnia (FMVZ), Universidade Estadual Paulista (Unesp), Distrito de Rubião Junior s/n, Botucatu, SP 18618-970, Brazil. *Corresponding author: anaalves@fmvz.unesp.br

${ }^{3}$ Hemocentro, Faculdade de Medicina de Botucatu (FMB), Unesp, Distrito de Rubião Junior s/n, Botucatu, SP.

${ }^{4}$ Departamento de Clínica Veterinária, FMVZ-Unesp, Distrito de Rubião Junior s/n, Botucatu, SP.
}

anticorpos monoclonais mouse anti-horse CD13, mouse anti-horse CD44 e mouse anti-rat CD90 foram utilizados para a caracterização imunofenotípica da superfície das SpCTMs. Estas células também foram cultivadas utilizando meio de cultura específico para a diferenciação adipogênica e condrogênica. Não houve expressão do marcador CD13, mas os marcadores CD44 e CD90 foram expressos em todas as passagens testadas. Após 14 dias da diferenciação das células em adipócitos, gotículas de lipídeos foram observados através da coloração com Oil Red O. Vinte e um dias após a diferenciação condrogênica, as células foram coradas com o Alcian Blue. Embora a técnica de isolamento destas células necessite ser otimizada, o presente estudo demonstra a caracterização parcial das SpCTMs, classificando-as como um tipo de células progenitoras promissoras para o uso na terapia celular em equinos.

TERMOS DE INDEXACAO: Caracterização imunofenotípica, diferenciação, células tronco mesenquimais, sangue periférico, equino. 


\section{INTRODUCTION}

Peripheral blood-derived multipotent mesenchymal stromal cells (PbMSCs) are cells isolated from the peripheral blood of adult animals by primary culture of plastic-adherent colonies of fibroblast-like cells, i.e., fibroblastic colony-forming units (CFU-Fs), which are similar to the CFU-Fs obtained in bone marrow-derived stromal cell cultures (He et al. 2007).

In horses, PbMSCs have exhibited therapeutic potential in studies that have analyzed their osteogenic, adipogenic (Koerner et al. 2006, Giovannini et al. 2008, Martinello et al. 2010), myogenic (Martinello et al. 2010) and chondrogenic (Giovannini et al. 2008) differentiation. Recently, the main focus of stem cell research has been based on therapeutic applications and the evaluation of regenerative potential. Considering the promise of translating the experimental results to clinical applications, further studies to confirm the reproducibility and safety of stem cell applications are required to support the transition from basic research to the clinic (Spencer et al. 2011).

The advantage of using PbMSCs is that collecting this material is safer and less invasive than bone marrow puncture (Ahern et al. 2011). However, due to the low concentration of progenitor cells in the mononuclear cellular fraction of peripheral blood and because these cells are very fragile and have a limited capacity for expansion, further studies are required to increase the cell yields and make therapeutic application viable (Koerner et al. 2006). Ahern et al. (2011) have unsuccessfully attempted to isolate and grow equine peripheral blood-derived progenitor cells by processing blood using an apheresis machine, confirming the difficulty in isolating and cultivating these cells.

Three minimum criteria for the characterization of human multipotent mesenchymal stromal cells (MSCs) have been established by the Mesenchymal and Tissue Stem Cell Committee of the International Society for Cellular Therapy (ISCT). First, the cells must adhere to plastic when maintained in standard culture conditions. Second, the MSCs must express CD73, CD90 and CD105 and must not express the CD34, CD45, CD14, CD11b, CD79, CD19 or MHC Class II antigens. Third, the MSCs must be able to differentiate into osteoblasts, adipocytes and chondroblasts in vitro (De Schauwer et al. 2011).

Cell surface expression may vary due to the different isolation techniques, methodology or culture time. Additional variation can come from the use of monoclonal antibodies that can detect different epitopes of the same surface protein and the different degrees of sensitivity of the flow cytometry analysis (Gimble \& Guilak 2003). There are also variations related to species, cellular origin (embryonic or adult) and the site of origin (Spencer et al. 2011). Currently, there is no single marker or set of markers that can verify the isolation and purification of MSCs without errors (Chen et al. 2008). The greatest difficulty in characterizing MSCs in veterinary medicine arises from the low number of monoclonal antibody markers and the evidence that some markers used in other species do not cross-react with the horse (Taylor et al. 2007). The only species-specific com- mercial antibodies that recognize equine epitopes are against CD13, CD44 and MHC Class II (De Schauwer et al. 2011). Therefore, further studies using different types of species-specific and non-species-specific markers are required to determine if interspecific cross-reactivity occurs and to establish whether these markers are expressed differently depending on the original source of the cells.

To date, only one study has demonstrated the immunophenotypic characterization of equine PbMSCs based on the expression of the CD13, CD44, CD90 and CD117 markers (Martinello et al. 2010). However, none of the antibodies used are specific for the horse.

The objectives of present work were the isolation and immunophenotypic characterization of the surface of $\mathrm{Pb}$ MSCs from horses. Furthermore, the study tested the ability of these cells to differentiate into adipocytes and chondrocytes.

\section{MATERIALS AND METHODS}

The protocol for this study was approved by the Ethics and Animal Behavior Committee of the School of Veterinary Medicine and Animal Science (number: 213/2008), São Paulo State University, Brazil, and all experiments were performed under the international guidelines for the care of research animals.

Blood samples were collected from the peripheral vessels of 4 adult animals ( 4 to 7 years old) of undefined breed. Prior to the start of the experiment, complete blood counts and physical exams were carried out in all animals to confirm their health. After shaving and aseptically preparing the jugular vein site, $36 \mathrm{~mL}$ of whole blood was collected in tubes containing 3.2\% sodium citrate anticoagulant (Becton, Dickinson and Company, Franklin Lakes, NJ, USA). The tubes were placed in specific support equipment for 20 minutes for the sedimentation of red blood cells. Subsequently, the plasma was carefully collected to avoid contamination with the erythrocytes and transferred to another $50 \mathrm{~mL}$ conical tube containing $15 \mathrm{~mL}$ of Histopaque ${ }^{\circledR} 1077$ (Sigma-Aldrich, St Louis, MO, USA). This tube was centrifuged at a relative centrifugal force of $1600 \mathrm{~g}$ for 20 minutes; after this centrifugation, the formation of a halo containing the blood mononuclear cells (containing progenitor cells) was observed. The mononuclear cells were quantified using a hemocytometer and subsequently plated in $25 \mathrm{~cm}^{2}$ petri dishes with DMEM/F12 (Dulbecco's Modified Eagle Medium/Ham's F-12) medium containing 20\% fetal bovine serum. The dishes were placed in a humidified incubator at $37^{\circ} \mathrm{C}$ with $5 \% \mathrm{CO}_{2}$ for 10 days without changing the culture medium so that the progenitor cells would adhere to the plastic. Subsequently, the culture medium was changed every 3 days, and when $70 \%$ confluence was reached, trypsinization and subsequent immunophenotypic characterization of the surface of the peripheral blood-derived progenitor cells were carried out.

For the flow cytometry analysis, the following 3 MSC surface antigen markers were used: CD13 (aminopeptidase-N), CD44 (HCAM) and CD90 (Thy-1). The cells were suspended in PBS mM EDTA at a concentration of $10^{6}$ cells/mL. Subsequently, $200 \mu \mathrm{L}$ aliquots of cells were transferred to flow cytometry tubes and incubated according to the instructions for each monoclonal antibody. Flow cytometry was carried out using a FACSCalibur flow cytometer (BD, Franklin Lakes, NJ, USA) in the first and second passages using mouse anti-rat CD90-FITC monoclonal antibody (Caltag Laboratories, Burlingame, CA, USA) to evaluate interspecies expression and the species-specific mouse anti-horse CD13 (AbD Serotec, Kidlington, Oxford, UK) and mouse anti-horse CD44 
(AbD Serotec, Kidlington, Oxford, UK) monoclonal antibodies, which were labeled with the secondary monoclonal antibody goat anti-mouse IgG-FITC (Molecular Probes, Eugene, OR, USA). A goat anti-mouse IgG-FITC antibody (Molecular Probes, Eugene, OR, USA) was used as a negative control. After incubation, the cells were washed with PBS and diluted in PBS nM EDTA.

For differentiation, the MSCs were trypsinized and placed in 6-well plates containing DMEM/F12 (1:1) medium, 20\% fetal bovine serum and antibiotic and antifungal agents. Forty-eight hours after incubation, the maintenance medium was removed, and STEMPRO $®$ (Gibco, Grand Island, NY, USA) adipogenic differentiation medium was added to the subculture. The medium was changed every 2 to 3 days, and the adipogenic differentiation was confirmed by demonstrating the presence of intracytoplasmic lipid droplets using Oil Red dye (Gibco, Grand Island, NY, USA).

For chondrogenic differentiation, the MSCs were cultured in a $3 \mathrm{D}$ pellet in a Falcon tube $(15 \mathrm{ml})$ for 21 days; STEMPRO® (Gibco, Grand Island, NY, USA) medium was used for chondrogenic differentiation and was changed every 3 days. The cell pellets were fixed with $10 \%$ buffered formalin for 24 hours and embedded in paraffin for histological sectioning into $5 \mu \mathrm{M}$-thick sections for staining and evaluation under a light microscope. To detect chondrogenic differentiation, the cells were stained with $\mathrm{pH} 2.5$ Alcian Blue and pH 1 Toluidine Blue.

\section{RESULTS AND DISCUSSION}

The techniques used in this study to isolate and culture PbMSCs proved to be safe and feasible for expanding the number of cells. Although the isolation of peripheral blood progenitor cells was possible, it was necessary to repeat the peripheral blood collection in 2 of the 4 animals due to a lack of adherence of the blood mononuclear cells after 10 days of culture. After the second blood collection in these animals, adherence was observed, and it was possible to isolate the PbMSCs.

After the first culture medium change, which was 10 days after whole blood collection and separation of the mononuclear fraction, the cells isolated from the equine peripheral blood took an average of 21 days to achieve $70 \%$ confluence. At this time, trypsinization, sample plating, flow cytometry analysis (Table 1) and adipogenic and chondrogenic differentiation were performed (Fig.1). The flow cytometry analysis indicated expression of CD90 marker in all cells isolated from both passages tested, indicating interspecies cross-reactivity between the rat and horse. Expression of the tested CD44 marker was also noted in the different passages of peripheral blood-derived progenitor cells (Fig.2). However, CD13 marker expression was not seen in the analysis performed, and this observation supports the results from previous studies using MSCs derived from adipose tissue (de Mattos Carvalho et al. 2009) and bone marrow (Radcliffe et al. 2010). CD13 was the only marker used in this study for which the results diverged.

Table 1. PbMSC marker expression by flow cytometry analysis

\begin{tabular}{ccc}
\hline Marker & P1 & P2 \\
\hline CD13 & $2.03 \% \pm 1.02$ & $1.82 \% \pm 0.94$ \\
CD44 & $91.30 \% \pm 12.30$ & $93.50 \% \pm 14.33$ \\
CD90 & $40.50 \% \pm 11.50$ & $60.40 \% \pm 19.66$
\end{tabular}

$\overline{\mathrm{P} 1}=$ 1st passage; $\mathrm{P} 2$ = 2nd passage.
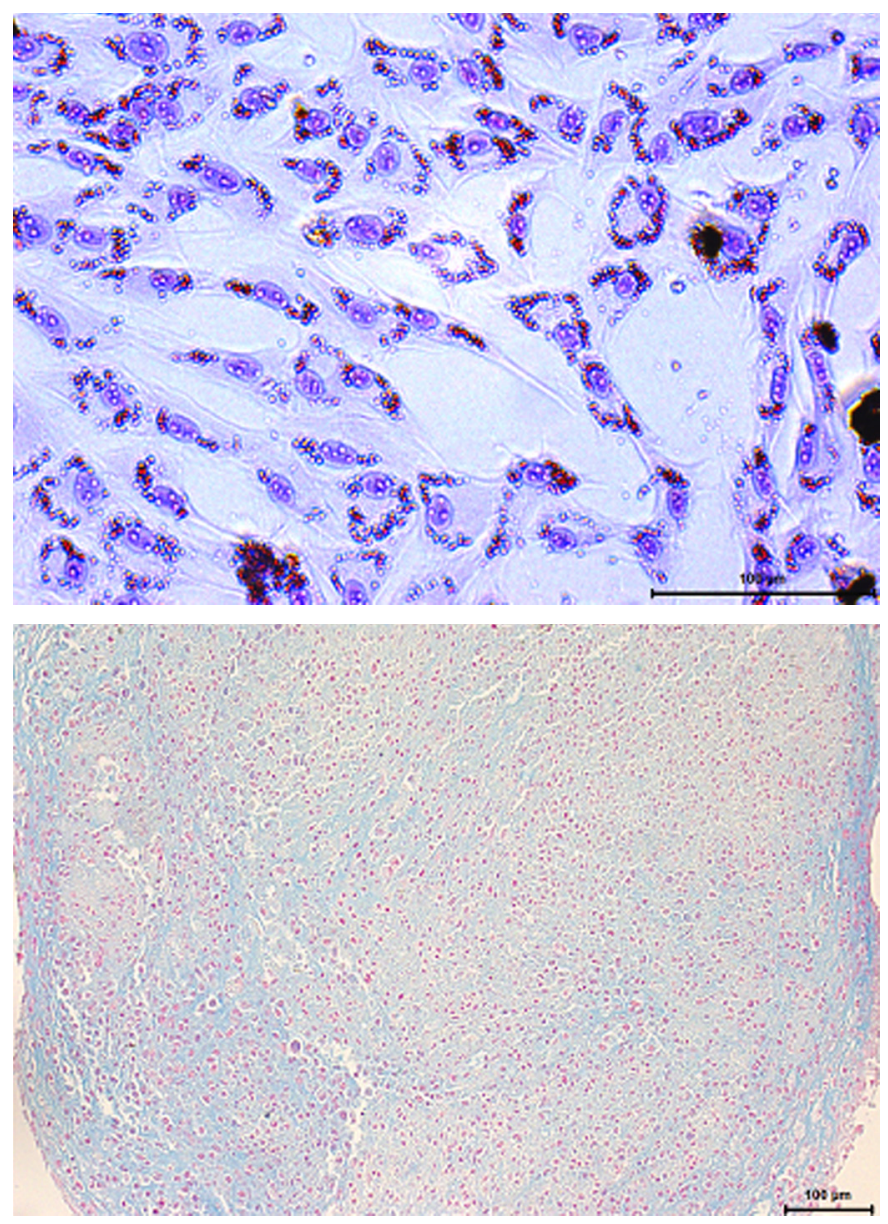

Fig. 1.(A) Image of PbMSCs (200x) at day 14 after differentiation into adipocytes; lipid droplets were detected by Oil Red-0. (B) Image of PbMSCs (100x) at day 21 after differentiation into chondrocytes; Alcian Blue staining shows the extracellular deposition of glycosaminoglycans.

A possible explanation for the described difference in expression of this marker between the two studies is that the present study used a mouse anti-horse CD13 antibody; according to Radcliffe et al. (2010), who tested this antibody, the CD13 marker did not react with the equine molecules. Conversely, Martinello et al. (2010) labeled PbMSCs with a non-species-specific CD13 marker and obtained an average expression of $77.5 \%$, whereas the average expression in the present study was $2.03 \%$.

The success rate for isolating equine PbMSCs has been reported to be 33\% (Koerner et al. 2006), 44\% (Martinello et al. 2010) and $66 \%$ (the present study), which is considered very low compared to other sources of stem cells, such as the bone marrow and adipose tissue, where there is normally completely successful isolation. A possible explanation for the greater difficulty in isolating equine $\mathrm{Pb}$ MSCs is that the concentration of stem cells circulating in peripheral blood is very low, thus hindering their isolation. The higher success rate for the isolation of blood progenitor cells obtained in this study compared to the rates reported by other authors is most likely because the blood mononuclear cells were maintained in primary culture for 10 days without changing the culture medium, thus favoring 

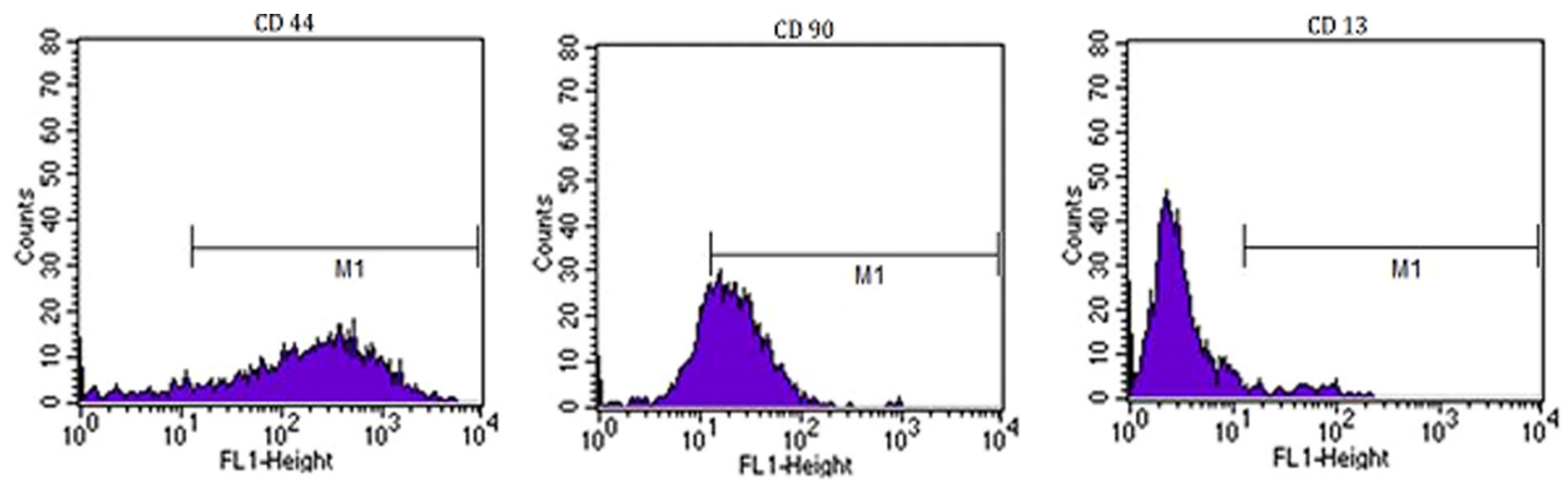

Fig.2. Immunophenotypic analysis of PbMSCs. Histogram representing the flow cytometry performed on the PbMSCs in the $1^{\text {st }}$ passage using the following markers: CD44, CD90, CD13.

the adherence of a larger number of progenitor cells to the Petri dish. Martinello et al. (2010), for example, incubated the mononuclear cells overnight and completely removed the non-adherent cells when changing the culture medium the following day.

In the present study, adipogenic and chondrogenic differentiation was achieved, as has been described by other authors (Koerner et al. 2006, Giovaninni et al. 2008, Martinello et al. 2010) who have confirmed that equine PbMSCs have the potential to differentiate into different lineages of mesodermal origin after exposure to specific culture conditions. He et al. (2007) have also stated that the isolation of peripheral blood-derived progenitor cells is not easy, possibly due to the low number of progenitor cells included in the mononuclear fraction, which decreases the frequency of colony-forming units (CFUs). Another factor that may influence the low CFU frequency during blood cell culture is the inadequate or unfavorable levels of growth factors present in the culture medium used.

The PbMSCs isolated and grown in the present study exhibited similar phenotypes to fibroblasts, consistent with the descriptions given by Giovaninni et al. (2008) and Martinello et al. (2010). Based on the results of the present study, the mouse anti-rat CD90 marker showed interspecies cross-reactivity, in accordance with de Mattos Carvalho et al. (2009), making this marker, along with CD29, CD105 and MHC I, one of the few exhibiting cross-reactivity that can be used for the characterization of equine MSCs (De Schauwer et al. 2011).

Our results, together with those previously reported in the literature (Koerner et al. 2006, Giovaninni et al. 2008, Martinello et al. 2010), led us to conclude that the properties of equine peripheral blood-derived progenitor cells, such as the culture characteristics, immunophenotypical expression of markers expressed in the mesodermal lineage and differentiation capacity, make this cell type a potential candidate for applications in cell therapy and tissue engineering. Blood is more accessible than bone marrow or adipose tissue, and the advantages of using peripheral blood as a source of MSCs are obvious. Nevertheless, because the concentration of these cells is lower in the peripheral blood compared to the bone marrow and adipose tissue, improvements to the isolation protocol and culture conditions are required to ensure a reasonable yield of pro- genitor cells before there can be clinical application of this technique in equine medicine.

Acknowledgments.- To São Paulo Research Foundation (FAPESP, 2009/10670-8) for financial support, and to Dr. Fernanda da Cruz Landim e Alvarenga, professor at Faculdade de Medicina Veterinária e Zootecnia, Unesp-Botucatu, for laboratory support.

\section{REFERENCES}

Ahern B.J., Schaer T.P., Terkhorn S.P., Jackson K.V., Mason N.J. \& Hankenson K.D. 2011. Evaluation of equine peripheral blood apheresis product, bone marrow, and adipose tissue as sources of mesenchymal stem cells and their differentiation potential. Am. J. Vet. Res. 72:127-133.

Chen Y., Shao J.Z., Xiang L.X., Dong X. \& Zhang G. 2008. Mesenchymal stem cells: a promising candidate in regenerative medicine. Int. J. Biochem. Cell Biol. 40:815-820.

De Mattos Carvalho A., Alves A.L.G., Golim M.A., Moroz A., Oliveira P.G.G., Hussni C.A. \& Deffune E. 2009. Isolation and immunophenotypic characterization of mesenchymal stem cells derived from equine species adipose tissue. Vet. Immunol. Immunopathol. 132:303-306.

De Schauwer C., Meyer E., Van de Walle G.R. \& Soom A.V. 2011. Markers of stemness in equine mesenchymal stem cells: A plea for uniformity. Theriogenology 75:1431-1443.

Gimble J.M. \& Guilak F. 2003. Adipose-derived adult stem cells: isolation characterization, and differentiation potential. Cytotherapy 5:362369.

Giovannini S., Brehm W., Mainil-Varlet P. \& Nesic D. 2008. Multilineage differentiation potential of equine blood-derived fibroblast-like cells. Differentiation 76:118-129.

He Q., Wan C. \& Gang L. 2007. Concise Review: Multipotent mesenchymal stromal cells in blood. Stem Cell 25:69-77.

Koerner J., Nesic D., Romero J.D., Brehm W., Mainil-Varlet P. \& Grogan S.P. 2006. Equine peripheral blood-derived progenitors in comparison to bone marrow-derived mesenchymal stem cells. Stem Cell 24:16131619.

Martinello T., Bronzini I., Maccatrozzo L., Iacopetti I., Sampaolesi M., Mascarello F. \& Patruno M. 2010. Cryopreservation does not affect the stem cell characteristics of multipotent cells isolated from equine peripheral blood. Tiss. Eng. C, Methods 16:771-81.

Radcliffe C.H., Flaminio J.B.F. \& Fortier L.A. 2010. Temporal Analysis of Equine Bone Marrow Aspirate During Establishment of Putative Mesenchymal Progenitor Cell Populations. Stem Cells and Development 19:269-282.

Spencer N.D., Gimble J.M. \& Lopez M.J. 2011. Mesenchymal Stromal Cells: past, present, and future. Vet. Surg. 40:129-139.

Taylor S.E., Smith R.K.W. \& Clegg P.D. 2007. Mesenchymal stem cell therapy in equine musculoskeletal disease: scientific fact or clinical fiction? Equine Vet. J. 39:172-180. 